\title{
Gender Discrepancies in Publication Productivity: Opportunities and Drawbacks in Writing and Publishing Research Results Articles
}

\author{
Hamamah $^{1}$, Ive Emaliana ${ }^{2}$, Ika Nurhayani ${ }^{3}$, Ressi M. Delijar ${ }^{4}$ \\ \{hamamah@ub.ac.id $\left.{ }^{1}\right\}$ \\ Universitas Brawijaya, Indonesia ${ }^{1,2,3,4}$
}

\begin{abstract}
Despite equal opportunities and supports into article publications, the gender gap persists for the outcomes. To reveal this divergence, the researchers examine some Indonesian lecturers' opportunities and challenges in publishing their research reports in some journals and relate it to gender discrepancies. Productivity of lecturers is studied through different indicators. Inter-gender differences, influence of professional category and age are analyzed. This research involved 89 participants from various universities across Indonesia and analyze their publications in the past 10 years $(2009-$ now $)$. We use mixed-methods research, employing survey study and interview to the participants. Our results indicate different motivations, feelings, views, and attitudes towards publishing in academic journal preferred across gender. A comparative analysis is presented to compare the productivity between men and women in article publications.
\end{abstract}

Keywords: Publication Productivity, Gender, Article Publications, Journal.

\section{Introduction}

Recently, Indonesia has been intensifying the efforts in advancing the number of international publications. In the world ranking system, publication is one of the standards for a nation's intellectual performance [1]. The efforts in increasing the number of publications which have been made are ranging from issuing rules that require lecturers to publish to giving rewards. The Ministry of Research, Technology and Higher Education has issued some regulations that demand the faculty members to increase the number of their publication in international journals [2]. Based on Regulation of The Minister of Research, Technology, and Higher Education of The Republic of Indonesia Number 20 of 2017, these regulations require the existence of scientific writings from each lecturer to get promotions and to get financial incentives. The financial rewards are given by The Ministry of Research, Technology provides for academics who can publish in reputable international journals. Some Higher education institutions, especially in institutions that are encouraged to enter the world ranking (QS Ranking) whose main indicator is the number of international publications, also provide financial rewards for the academics. For example, Universitas Brawijaya, based on Letter Number 2229/UN10/KU/2017, and Universitas Gadjah Mada, as explained in Warta SDM UGM Edisi Insentif Berbasis Kinerja [3].

Some research in this area in Indonesian context reported that this mandate to publish in international journals makes many academics who are not accustomed to writing in international scientific journals feel insecure [4]. It is because of the challenges that they face 
during the process of researching and publishing [5]. On the other hands, there are also researches which reported that the reward-system has been successful in increasing the number of scientific publications in Indonesia [6][7][8]. However, as far as the authors' knowledge, the available previous researches have not discussed much on gender differences in the publication performance of Indonesian academics, so there is not much information available yet on whether in Indonesian context male academics has similar performance or challenges on publication matters compared to female academics.

Meanwhile, previous researches from other countries have reported that there are differences on publication performance among different genders. A research conducted by Rigg et al [9] on the productivity of publications between men and women, found that men were more dominant in publications in reputable international journals in the field of geography. Women's publications, in this case in the field of geography, are increasing in the number of collaborative studies each year but not as the first author. Agreeing with the findings of Rigg et al [9], Prozesky [10] also found that men dominate publications in the field of Science and Technology Studies. Men in South Africa can produce twice as many articles in national journals as women. The productivity of women's publications was also researched by Eigenberg et al [11] in the field of criminal justice publication. The research findings of Eigenberg et al [11] also agree that the productivity of women's publications is lower than men. Not only that, men also dominate the position of the first author when conducting collaborative research with women. In contrast to other studies, Mayer et al [12] explained from the field of urologists that, the productivity of women's publications is actually the same as men. However, men in the field of urologists in the United States have more work experiences, besides that, many male academics occupy higher positions than women. Mayer et al [12] research used more complex data because it examines publication productivity by considering factors of academic rank.

A similar study by Mairesse et al [13] explains something different from other point of view, about why women are less productive than men in terms of publication of scientific papers. Mairesse et al [13] found that the reason women were not as productive as man was because of the role of women as mothers in the family.

That previous studies on gender differences on publication performance from countries other than Indonesia provide insights that knowing the different performance of male and female academics in publication is useful for Indonesia to develop some strategies in improving the performance of the academics. Based on that argument, this paper is written to provide some information on gender differences in publishing in Indonesian context. It discusses a part of the findings on a bigger study about publication performance of Indonesian academics. This paper aimed at reporting variation in response on opportunities and drawbacks that lead to divergent trends in publication productivity of academics in Indonesia.

\section{Research Methods}

\subsection{Participant and Research Context}

Mixed methods were employed in this research. Firstly, a survey was designed and conducted online through google form to Indonesian lecturers. 89 Indonesian lecturers (53 women and 37 men), ranging in age between 33 and 39 years participated in this study. This survey study was aimed at revealing demographic information including name, sex, email 
address, institution, career rank, educational background, number of publications and kinds of journal publications. In order to avoid any potential conflict of interest, consent forms were offered to all participants for their approval, willingness and availability to have interview about their publication experience more in details. Secondly, twelve respondents were purposely chosen based on gender differences (six male lectures and six female lecturers) and article publication performances, in particular, those with the highest number of publications and the lowest number of publications, each consist of three male lecturers and three female lecturers respectively. The interviews were done online through emails, and it was conducted in bahasa Indonesia, and later transcribed into English by the authors.

\subsection{Procedures and Interview Protocol}

A semi-structured interview protocol was constructed by employing cognitive interview technique [14] to gain insight by means of asking respondents specific questions to elicit additional information after they responded the survey. The writing research article challenges and opportunities theory were taken from Moreno et al. [15], was used as the basis of semistructured interview using the cognitive interview technique. This instrument measures the four key dimensions of demographic information, views about publishing, past experience and difficulties, and current strategies for writing research article. One question was added to complete opportunities dimension of the instrument about facilities provided by institution. The interview protocol began with the researchers sent questions, through email based on the dimensions above in the form of $w h$-questions and researchers received the answers after they sent back the responses online within two months.

\subsection{Data Analysis}

The interview results in the written forms were then categorized according to the two issues addressed: opportunities and drawbacks of research article publications. The patterns of opportunities and drawbacks across different genders were identified differentiated from the high frequency of article publications and the low one.

\section{Results and Discussion}

\subsection{General Differences in Publication Productivity}

This research results reveal lecturers research articles' publication across different genders. Table 1 depicted information about lecturers' article journal publications. 
Table 1. Article Journal Publications for Lecturers across Different Genders

\begin{tabular}{|c|c|c|c|c|c|c|c|c|}
\hline \multirow[t]{2}{*}{ Gender } & \multirow[t]{2}{*}{ N (\%) } & \multicolumn{5}{|l|}{ Journal types } & \multirow[t]{2}{*}{ Total } & \multirow[t]{2}{*}{ Mean } \\
\hline & & $\begin{array}{l}\text { Reputable } \\
\text { international }\end{array}$ & International & $\begin{array}{l}\text { Reputable } \\
\text { national }\end{array}$ & National & $\begin{array}{l}\text { Local } \\
\text { Campus }\end{array}$ & & \\
\hline Male & $\begin{array}{l}31 \\
(35 \%)\end{array}$ & $24(0.77)$ & $30(0.97)$ & $40(1.29)$ & $\begin{array}{l}83 \\
(2.68)\end{array}$ & $\begin{array}{l}22 \\
(0.71)\end{array}$ & 195 & 6.29 \\
\hline Female & $\begin{array}{l}58 \\
(65 \%)\end{array}$ & $46(0.79)$ & $92(1.59)$ & $69(1.19)$ & $\begin{array}{l}134 \\
(2.31)\end{array}$ & $\begin{array}{l}40 \\
(0.69)\end{array}$ & 377 & 6.5 \\
\hline Total & $\begin{array}{l}89 \\
(100 \%)\end{array}$ & 70 & 122 & 109 & 217 & 62 & 572 & \\
\hline
\end{tabular}

As indicated by Table 1, most female and male lectures that do publish tend to produce approximately six research articles equivalent. However, the means indicate that female lecturers in higher education institutions in Indonesia at least twenty one percent more publication than their male counterparts. Female-to-male means over article journal publication (6.5) is higher than the mean (6.29). This elucidates that difference exist between the sexes in the number of publications, but only little difference. However, based on journal types, female lecturers were more productive in publishing research articles in reputable international journals $(x=0.79)$ and international journal $(x=1.59)$, meanwhile male lecturers were more productive in publishing research articles in national reputable journals $(\mathrm{x}=1.29)$, national journals $(x=2.68)$, and local journals $(x=0.71)$ compare to female lecturers. In other words, female lecturers are more productive in publishing international journals, while male lecturers are more productive in publishing in local and national journals. Thus, closer inspection of opportunities and drawbacks which may relate to different article publication types need to reveal.

\subsection{Opportunities in Writing and Publishing Research Results Articles}

Table 2. Male and Female Lecturers' Motivations on Writing and Publishing Articles

\begin{tabular}{lll}
\hline Gender & High Frequency Publication & Low Frequency Publication \\
\hline Male & - academic rank qualification & - academic rank qualification \\
& - research reports & - research reports \\
& - remuneration & - expertise \\
\hline Female & - research reports & - research reports \\
& - academic rank qualification & - academic rank qualification \\
& - expertise and lecturers' duty & - expertise and lecturers' duty \\
\hline
\end{tabular}

Table 2 depicts summary of interview results across different genders with different frequency of research article journal publication. The primary findings related to opportunities in writing and publishing research articles revealed lecturers' great desire to publish articles in journals because of several reasons. Female lecturers have several motivation forces which make them put efforts to publish, including as outputs for research, one of qualifications for academic rank promotion, and one of implementation of individual research roadmap to develop expertise in their field. 


\subsection{Drawbacks in Writing and Publishing Research Results Articles}

Table 3. Male and Female Lecturers' Challenges on Writing and Publishing Articles

\begin{tabular}{|c|c|c|}
\hline Gender & High Frequency Publication & Low Frequency Publication \\
\hline \multirow[t]{3}{*}{ Male } & $\begin{array}{l}\text { Limited number of national Journals with } \\
\text { A or B accreditations. }\end{array}$ & Writing quality \\
\hline & Manuscripts guide and templates. & Lack of English competence. \\
\hline & Lack of English competence & Templates. \\
\hline \multirow[t]{4}{*}{ Female } & $\begin{array}{l}\text { Waiting too long for editorial board } \\
\text { decisions. }\end{array}$ & Writing quality. \\
\hline & Complex journal selections. & Research quality. \\
\hline & $\begin{array}{l}\text { Limited number of national Journals with } \\
\text { A or B accreditations }\end{array}$ & Expertise. \\
\hline & & Lack of English competence \\
\hline
\end{tabular}

Table 3 provides information about drawbacks across different genders with various frequency of research article journal publication. Based on the interview results, several challenges in writing and publishing research results articles are varied based on linguistics feature problems, and non-linguistics feature problems. Upon linguistics feature problems cover academic writing quality difficulties and lack of good command of English language as the medium of communication with the journal editors as well as in preparing article manuscripts. Besides that, different templates of each journal make the lecturers spend some time to adjust and revise their manuscripts, moreover, some manuscript guidelines are not clear, for some ambiguous instructions are presented. Meanwhile, non-linguistics problems consist of time consuming of preparing manuscript and waiting for editorial board decisions or manuscript reviewing process, limited numbers national journals with $\mathrm{A}$ or $\mathrm{B}$ accreditation for social science studies.

\subsection{Strategies in Writing and Publishing Research Results Articles}

Table 4. Male and Female Lecturers' Strategies on Writing and Publishing Articles

\begin{tabular}{lll}
\hline \multicolumn{1}{c}{ Gender } & \multicolumn{1}{c}{ High Frequency Publication } & \multicolumn{1}{c}{ Low Frequency Publication } \\
\hline Male & - Employing proof readers & - Join research \\
& - Join research & - Single author \\
\hline Female & - Join research & - Join research \\
\hline
\end{tabular}

Table 4 shows summary on interview results about strategies to increase article publications. Some strategies are suggested by both male and female lectures to motivate their productivity to publish their research results articles. One strategy offered is join research to have join publication with more competence colleagues in terms of linguistics features and non-linguistic features competences.

Based on the results above, research productivity, particularly on article publication has shown that female lecturers publish a little bit more compare to male lecturers. It has been known that on academic productivity women publish less than men across all disciplines [16]. This study is also inconsistent with previous studies which mostly show that women are disproportionately underrepresented to be outperform for article publication [10]. 
Notwithstanding, the present research supports Eigenberg \& Whalley [11] which revealed that women's participation in the publication has increased.

\section{Conclusion}

The current study findings indicate that although women's overall participation in the publication process appears to outperform, but not really significant. This study results raise concerns that women are taking part in increasing research productivity as well as research results publication, as article publication in one of outlets for dissemination of research. Nevertheless, it is generally the most important criterion for evaluating a researcher's work. Comparing the genders in terms of their article publications can thus become a valuable device to map women's current research productivity, as well as their status in academia, related to that on men.

Limitations of this study bring recommendation for future research. Although the increases in women's participation are important, more attention need to be paid to authorship patterns and roles, for example by seeking more information about gender discrepancies based on corresponding authors, collaborative authors, main/single author, or journal reviewers or editors. Different approach of research methodologies can be employed to verify or against this research findings to enrich the area of study.

\subsection{Acknowledgment}

The authors would like to express their appreciation for the support of the sponsors with Institute of Research and Community Services (LPMM) Universitas Brawijaya for Hibah Penelitian Guru Besar dan Doktor No. 1483.3/UN10.F12/PN/2019.

\section{References}

[1] S. Marginson and M. Van der Wende, "To rank or to be ranked: The impact of global rankings in higher education," J. Stud. Int. Educ., vol. 11, no. 3-4, pp. 306-329, 2007.

[2] Kementerian Ristekdikti, "Permenristekdikti 20-2017 Pemberian Tunjangan," 2017.

[3] Direktorat Sumber Daya Manusia Universitas Gadjah Mada, Warta SDM UGM Edisi Insentif Berbasis Kinerja. Yogyakarta: Universitas Gadjah Mada, 2018.

[4] S. Arsyad, B. K. Purwo, K. E. Sukamto, and Z. Adnan, "Factors hindering Indonesian lecturers from publishing articles in reputable international journals," J. English as a Foreign Lang., vol. 9, no. 1, pp. 42-70, 2019.

[5] Z. Adnan, "Some potential problems for research articles written by Indonesian academics when submitted to international English language journals," Asian EFL J. Q. March 2009 Vol. 11, Issue, p. 107, 2009.

[6] T. Sandjaya and R. D. Muliawan, "Produktivitas Penulisan Artikel Jurnal Ilmiah Di Kalangan Dosen Fakultas Ilmu Sosial Dan Ilmu Politik Universitas Padjadjaran,” Kandaga-Media Publ. Ilm. Jab. Fungsional Tenaga Kependidikan, vol. 1, no. 1, 2019.

[7] E. Elfindri, S. Rustad, N. Nizam, and D. Dahrulsyah, "Lecturer Performances in Indonesia Higher Education System," Int. e-journal Adv. Educ., vol. 1, no. 1, pp. 26-36, 2015.

[8] M. Muhardi and A. Nurcahyo, "Pengaruh Tunjangan Sertifikasi terhadap Produktivitas Dosen dalam Menghasilkan Karya Ilmiah dan Penelitian," Pros. SNaPP Sos. Ekon. dan Hum., vol. 2, no. 1, pp. 99-106, 2011. 
[9] L. S. Rigg, S. McCarragher, and A. Krmenec, "Authorship, collaboration, and gender: Fifteen years of publication productivity in selected geography journals," Prof. Geogr., vol. 64, no. 4, pp. 491-502, 2012.

[10] H. Prozesky, "Gender differences in the journal publication productivity of South African academic authors," South African Rev. Sociol., vol. 37, no. 2, pp. 87-112, 2006.

[11] H. M. Eigenberg and E. Whalley, "Gender and publication patterns: Female authorship is increasing, but is there gender parity?," Women Crim. Justice, vol. 25, no. 1-2, pp. 130-144, 2015.

[12] E. N. Mayer, S. M. Lenherr, H. A. Hanson, T. C. Jessop, and W. T. Lowrance, "Gender differences in publication productivity among academic urologists in the United States," Urology, vol. 103, pp. 39-46, 2017.

[13] J. Mairesse, M. Pezzoni, and F. Visentin, "Impact of family characteristics on the gender publication gap: evidence for physicists in France," Interdiscip. Sci. Rev., vol. 44, no. 2, pp. 204-220, 2019.

[14] G. B. Willis, "Cognitive interviewing in practice: Think-aloud, verbal probing, and other techniques," Cogn. interviewing a tool Improv. Quest. Des. [Internet]. Thousand Oaks, Calif, pp. 42-65, 2005.

[15] A. I. Moreno, J. Rey-Rocha, S. Burgess, I. López-Navarro, and I. Sachdev, "Spanish researchers' perceived difficulty writing research articles for English-medium journals: The impact of proficiency in English versus publication experience," Ibérica Rev. la Asoc. Eur. Lenguas para Fines Especificos, vol. 24, pp. 157-183, 2012.

[16] Y. Xie and K. A. Shauman, "Sex differences in research productivity: New evidence about an old puzzle," Am. Sociol. Rev., pp. 847-870, 1998. 